\title{
The Use of Information and Communications Technology (I.C.T.) in Gifted Students
}

\author{
https://doi.org/10.3991/ijes.v7i2.10815 \\ Eirini Zoi Kontostavlou( $\left.{ }^{\bowtie}\right)$, Athanasios S. Drigas \\ National Center for Scientific Research "Demokritos", Attica, Greece \\ eirini.kontostavlou@gmail.com
}

\begin{abstract}
This article aims at considering the use of Information and Communications Technology (ICT) in gifted education and highlight the best ICT techniques for gifted students. The use of ICT in special education and specifically in gifted education has proved effective. ICTs techniques can be used by teachers to make intervention to the gifted, which will be very useful for them as they could develop their abilities and skills. In this report we provide a brief review of the most representative articles for ICT techniques, which have been used for giftedness. Pupils who are gifted in ICT are also presented.
\end{abstract}

Keywords - Information and Communication Technology (ICT), ICT techniques, gifted, giftedness

\section{$1 \quad$ Introduction}

The rapid growth of technology has led Information and Communications Technology (ICT) to become the cornerstone of everyday life, which is extremely dysfunctional without some facet of technology. We use mobile phones, laptops, tablets and other devices of new technology in every aspect of our life on a daily basis. It is a fact that technology has changed everything and education has been affected by it. ICT can be used for students with different educational needs and characteristics [1].

The term special educational needs includes a number of problems and difficulties in learning. Also, into this category, fall gifted students, who, despite the dominant perception that their academic success is given, face many problems. The definition of gifted students is not easy. Although many definitions have tried to describe them, none of them is precise. In general terms, gifted children are individuals with special talents, intelligence and high IQ rate. The difficulty of defining the gifted occurs because they are not a homogeneous team but they share some common characteristics. The most common characteristics are: curiosity, initiative, imagination, originality, creativity, dedication to what they do and love for learning.

Robert Sternberg in the Triarchic Theory of Intelligence believes that successful intelligence is comprised of three different factors: analytical intelligence, creative intelligence and practical intelligence [2]. He, also, believes that an individual person may be gifted either because it has increased one of the skills or because it has the way to balance the skills to reach success. So intelligence is not a fixed entity but a dynamic 
one [3]. According to Renzulli and the theory of the Three - Ring Conception gifted pupils have above average ability, task commitment and creativity [4].

Some important characteristics of gifted students are:

- They learn rapidly, easily and efficiently.

- They have a wide range of interests.

- They are good guessers and makes hypotheses.

- They like to study some subjects more than other ones.

- They have a long attention span in the areas of knowledge.

- They have creative thinking

- They have problem solving thinking.

- They provide multiple solutions or responses to problems.

- They achieve good grades in most of the subjects.

- They concentrate on a task.

- They ask more questions.

- They are curious and have unusual ideas.

- They prefer to work on their own.

- They come up with new solutions.

They are used to supporting their ideas [5].

Nowadays it is predominant to believe that gifted children are good students and that their success is certain. However, it is very likely that these children get bored more easily and they lose interest in school, especially when the class becomes sterilized. On the other hand, it is quite possible that educators do not recognize their abilities. Therefore, these students are neglected and left behind. Using ICT could help educating gifted students.

\section{Methodology}

This paper considers the relation between ICT and gifted students. Through the bibliographic review we tried to investigate if using ICT is helpful for those students. We found many reports and articles. We mostly attempted to find ICT techniques that could help intervene to the gifted. Through the study of bibliography references we found out that many articles claimed that some gifted students have a particular inclination to ICT. For that reason, we decided to add a chapter with this subject.

\section{$3 \quad$ ICT in education}

The rapid development of technology in the last decades has changed the world and the use of it affects our lives daily. As a result, the education could not remain unaffected by all these changes in technology as the basic needs of education have also changed. Modern education should keep up with technology so it should use ICT. An additional reason for their use is that they can bridge the gap between different educational needs. 
Mooij [6] suggests that with ICTs the teacher can design diversified educational programs for different pupils. It is a fact that high ability students need cognitive stimulation to be able to bring out their special abilities. These activities offer more challenging achievements and enrichment. They can also help gifted students to integrate into different areas of activities. Giftedness needs to be supported at school. So, the most effective way is through ICT. In an additional research, Mooji [7] presents a conceptual framework in which ICT can help the learning process through a diversified education system for all students. Therefore, individual characteristics should be considered in order to optimize the learning of each student. Such practices enhance the integration of learning differences

Additionally, Sheffield [8] believes that technology correlates to education for three reasons. Firstly, technology is an integral part of teenage life. Secondly, teachers should prepare young children for the world of tomorrow, in which new technology plays a vital role. Thirdly, gifted and talented students could become more effective, because when they use ICT, they utilize their skills. It is obvious that technology can enable students to develop their creativity and their individual characteristics. Today young people live in a digital world. Therefore, if they want to be successful and effective they have to follow the new reality.

Another research in technology in gifted students; Periathiruvadi and Rinn [9] believe that technology could serve gifted minds in order to advance their critical thinking and their social-emotional needs. Teachers can use technology to promote the gifted minds without disregarding the interests of students and, at the same time equip them with important skills of tomorrow.

Wells [10] presents a more computer-based curriculum in order to take the students beyond a conventional one. Every day our children are exposed, outside school, to innovations and advances of technological outcomes. Nevertheless, this new technological development does not transfer into the classroom special programs and the curriculum is not based on reality.

We can use many techniques to bridge the gap between the gifted students' needs and what actually happens at schools. Technology gives the boost to develop the cognitive skills which improve the learning of gifted and talented students. Using these techniques, the gifted will feel productive, creative and confident. They will be able to develop their special skills and interests, to enhance their creativity, to explore further knowledge beyond the common and to fulfill their personal needs. Thus, they will not feel that they are in the margins and they are the forgotten children of the class. On the contrary, they will feel active members of the classroom.

\section{$4 \quad$ ICT techniques}

There is a very important research which encourages the use of ICT in the learning environment. This chapter contains a review of some developments in this direction. 


\subsection{Mobile learning}

Mobile learning is an uprising and very promising form of learning. Actually, it is the next generation of e-learning. The transition towards mobile services has also influenced the sector of learning. The use of smartphones gives access to educational resources everywhere and anytime. Mobile learning or $\mathrm{m}$ learning is any form of learning that exploits the potential offered by wireless portable technologies and it takes place without the trainee having to be at predetermined points. Sharples et al. believe that we live in the age of mobility, where devices like phones, tablets and laptops are constantly moving and conducting everywhere. For that reason, education must be designed in such a way as to connect people with the virtual world and to create mobile learning communities. Thus, learning will not take place in a specific location but will move in space, time, themes and technologies [11].

According to Traxler [12], mobile learning is a concept that needs clarification. He observes that due to the ubiquitous diffusion of technology, the nature of knowledge is constantly changing and thus altering the way in which learning disseminates, as well. Also, mobile learning supports personalized learning, which acknowledges the different and can support individualized and individual learners. So, students can take advantage of space and time to expand their knowledge.

A central task in the design of gifted education is to promote programs enriched according to the mobility learning. According to Sharples et al., [13] a first step to the theory of mobile learning is to distinguish how $\mathrm{m}$ learning differs from other learning processes and what makes it outstanding. Secondly, mobile learning must include procedures both within and outside the classroom. Thirdly, mobile learning should rely on modern day practices to be successful. Lastly, the theory of mobile learning must take into consideration the ubiquitous use of technology. Abiding by the theory of mobile learning, mobile technologies can aid the learners' learning experience.

Moreover, mobile learning could assist to individual learning, focusing on the needs of each student. Cobcroft et al. [14] claim that mobile technologies are able to advocate creativity, collaboration, critical learning activities and communication with other students. There is a great diversity in how teachers and students can use these digital media. In this way, gifted students will have access to all those outlets to express their special talents and to be more active in the classroom.

\subsection{Digital classroom}

A digital classroom has the characteristics of a 'traditional class' but it does not require the actual presence of the individuals. The common place of the students is the network, not the classroom. A virtual class gives the opportunity to the students to share their questions, their thoughts and they have the ability to communicate with each other through the web.

Gifted students need a class without boundaries and limitations where they can use their unique and special learning needs. The digital classroom is an innovative technique, which can be used to gifted students. Certainly, it is a fact that contemporary students, according to Prensky [15] are the generation who is growing up with new 
technology and for that reason he calls them "digital natives", because they are "native speakers" of the digital language of laptops, phones, internet and other media.

The digital classroom has no limitations to space and time and it is a classroom without boundaries. The gifted can use technology to look up information about things that they are interested in and to communicate easily with others using social applications. Because of their ability to absorb a lot of information and process it even faster, they need a vast variety of knowledge to use in their own way. Moreover, the digital classroom provides the gifted with the opportunity to interact with each other inside and outside the classroom [16].

Xenos [17] suggests some common features of the digital classroom like video, chat, students feedback feature, whiteboard, slide presentation and discussion administrator feature. Additionally, Robin [18] proposes the digital storytelling as a powerful technology tool for the digital classroom. Digital storytelling is an application that helps students to become creative storytellers about a topic. This can enable gifted students to develop their skills, become creative and lead to higher order thinking. Finally, one powerful tool is wikis, which can help the cooperative work allowing users to manage, add, change, and delete information. Wikis is a source of information and knowledge where students could construct their knowledge [19].

\subsection{Online discussion}

Another ICT technique that could be used for gifted students is online discussion. Online discussion consists of virtual "discussion" rooms, where students can discuss a variety of topics in a synchronous or an asynchronous way. A discussion room constitutes a communication tool [20]. With this method the gifted can communicate with other gifted students and it can prove very useful for them, because they come into contact with other "like minds".

Marra et al. [21] believe that online discussion groups are an integral part of online courses. They promote critical thinking, problem solving, facilitate the higher order thinking and help in the construction of knowledge. Furthermore, according to Andresen [22], asynchronous discussion groups need two components to be successful: the role of the instructor and the achievement of higher order thinking. According to Beuchot and Bullen [23], the instructor should pay attention to the social and emotional climate of online groups and the interaction of students is very important.

Online discussion groups result in the improvement of social communication with gifted students. Because the number of gifted students is not very frequent, the online group can help these children communicate with each other. This will have the effect of feeling less isolated.

\section{$5 \quad$ Gifted in I.C.T.}

As we have mentioned before, gifted students are not a homogeneous team but they share some common characteristics. Also, as we know, many of them are quite capable of performing many activities and they have special talents. Technology could be 
one of them. In conclusion, we should mention in this review the gifted students in ICT.

It is possible amongst the gifted students that some have excellent abilities in ICT and are computer technology talented. The students that are gifted and talented in ICT should be recognized as unique talents in this domain in order to be able to develop their potential. According to Siegle [24], there is a great variety of talents, one of which is the talent in technology. The most important thing is the recognition of this talent and the characterization of this student as technologically gifted.

In addition, O'Brien et al. [25] establish that there are two categories of computer technology talents. The first is computer programming and the second is interfacing. In another study, O'Brien [26] believes that the talented in computer technology combine high-tech computer knowledge with the ability of higher knowledge. Also, in his research O'Brien tries to find the features that mark the development of this talent and categorizes them based on Gagné's Differentiated Model of Giftedness and Talented (DMGT) in four categories: a) natural abilities, b) intrapersonal catalyst, c) environmental catalysts, d) talent.

The gifted and talented in technology have a positive perception of the use of ICT in education, they want to expand their knowledge in this field and create new ideas and skills. Gifted students should be recognized and then supported by experts in ICT in order to cultivate their talent and even surpass them, when they are experts in this field. By acquiring these skills, the gifted can satisfy their curiosity [27].

Hook [28] believes that they can be gifted in using ICT, which has common characteristics: using ICT easily despite their age, learning very quickly ICT techniques, taking initiatives, using the ICT creatively, solving problems and developing their interests and their skills.

\section{Conclusion}

The scope of this study was to present how new technology and especially Information and Communication Technology (ICT) can support gifted students. From the finding of this study we analyzed that gifted students could have a variety of benefits and gain many advantages from the use of ICT in gifted education. Gifted students who have special educational skills must also be treated in a special way. The use of ICTs techniques can help in this direction and have a decisive role in shaping knowledge and skills. By using appropriate educational tools that technology offers the gifted can become more active members by using their special skills and talents. We have to understand that ICT is a very useful tool, which can help these students, because it has the potential to create effective and independent environments ideal for individualized education and intervention. In general, the personalized intervention programs are ideal for the gifted and can have optimum results. In addition, we believe that, nowadays, technology is ubiquitous and therefore must be used by the educational system. Finally, we consider that the field of gifted education and intervention via ICTs techniques need more research. 


\section{$7 \quad$ References}

[1] A. Drigas, R- E Ioannidou, "ICTs in Special Education: A Review", Commun. Comput. Inf. Sci., vol. 278, pp. 357-364, 2013.

[2] R. J. Sternberg "Toward a triarchic theory of human intelligence". Behavioral and Brain Sciences, vol. 7, no. 2, pp. 269-287, 1984. https://doi.org/10.1017/s0140525x00044629

[3] R. J. Sternberg, E. L. Grigorenko, "Successful intelligence in the classroom". Theory into practice, vol. 43, pp. 274-280, 2004. https://doi.org/10.1353/tip.2004.0049

[4] J. Renzulli, "Reexamining the Role of Gifted Education and Talent Develop-ment for the 21st Century: A Four-Part Theoretical Approach". Gifted Child Quarterly vol. 56, no. 3, pp. 150-159, 2012. https://doi.org/10.1177/0016986212444901

[5] J. Trna, "IBSE and gifted students". Science Education International, vol. 25, no. 1, pp.1928, 2014.

[6] T. Mooij, "Designing instruction and learning for cognitively gifted pupils in preschool and primary school". International Journal of Inclusive Education vol.17, no.6, pp. 597613, 2013. https://doi.org/10.1080/13603116.2012.696727

[7] T. Mooij, "Design of educational and ICT conditions to integrate differences in learning: Contextual learning theory and a first transformation step in early education". Computers in Human Behavior, vol. 23, no. 3, pp. 1499-1530, 2007. https://doi.org/10.1016/j.chb.2005.07.004

[8] C. C. Sheffield, "Technology and the Gifted Adolescent: Higher Order Think-ing, 21st Century Literacy, and the Digital Native". Meridian: A Middle School Computer Technologies Journal, vol. 10, no, 2, pp. 1-10 2007.

[9] S. Periathiruvadi, A. Rinn, "Technology in Gifted Education". Journal of Re-search of Technology in Education, vol. 45, no. 2, 153-169, 2014.

[10] D. Wells, "Computing in schools: time to move beyond ICT?" Research in Secondary Teacher Education, vol. 2, no. 1, pp.8-13, 2012.

[11] M. Sharples, I. Arnedillo-Sanchez, M. Milrad \& G. Vavoula, "Mobile Learning: Small devices, big issues". Technology - Enhanced Learning: Principles and Products, Chapter 14, pp. 233-249, Springer Netherlands, 2009. https://doi.org/10.1007/978-1-4020-9827-7 14

[12] J. Traxler, "Defining, discussing, and evaluating mobile learning: The moving finger writes and having write". International Review of Research in Open and Distance Learning, vol. 8, no 2, pp.1-12, 2007. https://doi.org/10.19173/irrodl.v8i2.346

[13] M. Sharples, J. Taylor, G. Vavoula, "Towards a Theory of Mobile Learning”. Mobile Technology: The Future of Learning in Your Hands. mLearn 2005 Book of Abstracts, 4th World Conference on $\mathrm{m}$ Learning, 2005.

[14] R. Cobcroft, S. Towers, J. Smith \& A. Bruns, "Mobile learning in review: Opportunities and challenges for learners, teachers, and institutions". Proceed-ings Online Learning and Teaching (OLT) Conference 2006, pp. 21-30, 2006.

[15] M. Prensky, "Digital Natives, Digital Immigrants". On the Horizons, NCB University Press, vol. 9, no. 5, pp.1-6, 2001.

[16] A.Y.A. Bakar, "Digital Classroom: An Innovative Teaching and Learning Technique for Gifted Learners Using ICT". Creative Education, vol. 7, pp. 55-61, 2016. https://doi.org/10.4236/ce.2016.71006

[17] M. Xenos, "The Future of Virtual Classroom: Using Existing Features to Move Beyond Traditional Classroom Limitations". In: Auer, M., Tsiatsos, T. (eds) Interactive Mobile Communication Technologies and Learning, Springer, vol. 725, pp. 944-951, 2018. https://doi.org/10.1007/978-3-319-75175-7_92 
[18] B, R. Robin, "Digital Storytelling: A Powerful Technology Tool for the 21st Century Class". Theory into Practice, vol. 47, pp. 220-228, 2008. https://doi.org/10.1080/00405840802153916

[19] K. Parker, J. Chao, "Wiki as a Teaching Tool”. Interdisciplinary Journal of Knowledge and Learning Objects, vol. 3, pp. 57-72, 2007.

[20] M. Flecknoe, "How can ICT Help us to improve Education?", Innovations in Education and Teaching International, vol. 39, no. 4, pp. 271-279, 2010. https://doi.org/10.1080/13558000210161061

[21] R. Marra, J. Moore, A. Klimczak. "Content Analysis of Online Discussion Forums: A Comparative Analysis of Protocols". Educational Technology Re-search and Development, vol. 52, no. 2, pp. 23-40, 2004. https://doi.org/10.1007/bf02504837

[22] M. Andresen, "Asynchronous discussion forums: success factors, outcomes, assessments and limitations". Educational Technology \& Society, vol. 12, no. 1, pp. 249-257, 2009.

[23] A. Beuchot, M. Bullen, "Interaction and Interpersonality in Online Discussion Forms". Distance Education, vol. 26, no. 1, pp. 67-87, 2005. https://doi.org/10.1080/01587910500081285

[24] D. Siegle, "Identifying Students with Gifts and Talents in Technology". Gifted Child Today, vol. 27, no. 4, pp. 30-33, 2004. https://doi.org/10.4219/gct-2004-146

[25] B. O'Brien, R. Friedman-Nimz, J. Lacey, D. \& Denson, "From Bits and Bytes to C++ and Websites: What is Computer Talent Made of?" Gifted Child To-day, vol. 28, no. 3, pp. 5664, 2005. https://doi.org/10.4219/gct-2005-178

[26] B. O'Brien, “Gifted geeks: The emergence and development of computer technology talent". Available from ProQuest Dissertation \& Theses: Full Text, 2007.

[27] M. Ahmad, J. Badusah, A. Z. Mnasor, \& A. A Karim, "The Discovery of the Traits of Gifted and Talented Students in ICT". International Education Stud-ies, vol. 7, no. 13, pp. 92-101, 2014. https://doi.org/10.5539/ies.v7n13p92

[28] P. Hook, "ICT and Learning: The iPaint Experience". Computers in New Zea-land Schools, vol.16, no. 3, pp.15-21, 2004.

\section{Author}

Eirini Zoi Kontostavlou renders honourable services at the national center for Scientific Research "Demokritos", in Attica, Greece.

Athanasios S. Drigas also works for the National Center for Scientific ResearchDemokritos, Attica, Greece

Article submitted 2019-04-07. Resubmitted 2019-05-13. Final acceptance 2019-05-21. Final version published as submitted by the authors. 